\title{
The linkage between work-related factors, employee satisfaction and organisational commitment: Insights from public health professionals
}

\author{
Authors: \\ Chengedzai Mafini ${ }^{1}$ \\ Nobukhosi Dlodlo \\ Affiliations: \\ ${ }^{1}$ Department of Logistics, \\ Vaal University of \\ Technology, South Africa \\ ${ }^{2}$ Department of Marketing, \\ Vaal University of \\ Technology, South Africa \\ Correspondence to: \\ Chengedzai Mafini \\ Email: \\ chengedzai@hotmail.com \\ Postal address: \\ Private Bag X021, \\ Vanderbijlpark 1900, \\ South Africa
}

Dates:

Received: 15 Dec. 2013

Accepted: 16 Apr. 2014

Published: 29 Aug. 2014

How to cite this article:

Mafini, C., \& Dlodlo, N

(2014). The linkage between

work-related factors,

employee satisfaction and

organisational commitment:

Insights from public health

professionals. SA Journal

of Human Resource

Management/SA Tydskrif vir

Menslikehulpbronbestuur,

12(1), Art. \#616, 12 pages.

http://dx.doi.org/10.4102/

sajhrm.v12i1.616

\section{Copyright:}

(C) 2014. The Authors.

Licensee: AOSIS

OpenJournals. This work

is licensed under the

Creative Commons

Attribution License.
Read online:

Scan this $Q R$ code with your smart phone or mobile device to read online.
Orientation: The public health sector in South Africa faces a number of human resourcerelated inundations. Solving these challenges requires the provision of empirically derived information on these matters.

Research purpose: This study investigated the relationship between three work-related factors, person-environment fit, work-family balance and perceived job security, and employee satisfaction and organisational commitment. A conceptual framework that links these factors is proposed and tested.

Motivation for the study: The prevalence of employee-related challenges involving public health professionals, as evidenced through industrial action and high labour turnover, amongst others, demands further research in order to generate appropriate solutions.

Research approach, design and method: A quantitative design using the survey approach was adopted. A six-section questionnaire was administered to a stratified sample of 287 professionals in three public health institutions in Gauteng, South Africa. Data was analysed using descriptive statistics, exploratory factor analysis, Pearson's correlation analysis and regression analysis.

Main findings: Job security and person-environment fit both positively correlated with and predicted employee satisfaction. The association between work-family balance and employee satisfaction was weak and showed no significant predictive validity. Employee satisfaction was strongly correlated to and predicted organisational commitment.

Practical/managerial implications: The findings of the current study may be used by managers in public health institutions to improve the level of organisational commitment amongst professionals in the sector, thus preventing further employee-related challenges that negatively affect the provision of outstanding public health services.

Contribution: The study provides current evidence on how both work-related and humanrelated factors could contribute to the prosperity of the public health sector, both at micro and macro levels. The study also provides updated insights into the interplay between these factors in the context of South Africa, thereby addressing a research gap in this subject.

\section{Introduction}

As the costs of health services continue to soar in South Africa, the heavily subsidised public health sector has emerged as the major health service provider for the greater South African populace (Pillay, 2009). However, several challenges, emanating from both the internal and external environment, have mushroomed that tend to inhibit the ability of public health institutions to achieve their goals. In the external environment, a major challenge relates to increasing competition from the private health services providers (George, Gow \& Bachoo, 2013). However, on the internal front, the principal impediment is the increasing number of cases of disgruntlement amongst public health professionals. This is evidenced by episodic industrial action in the sector as well as the high staff turnover amongst health professionals who may be destined for greener pastures in Western countries (Dhai, Etheredge, Vorster \& Veriava, 2011). As suggested by Blaauw et al. (2013), public health professionals have the potential to be part of the central government's solution to key problems within the health-care systems. It is important then, to investigate the significant predictors of employee satisfaction and how the latter may subsequently contribute to the development of organisational commitment. This will clearly contribute to managerial solutions to the problems that are currently entrenched in the public health-care system.

In response to various developments in the South African public health sector, a number of fairly recent research projects have been conducted to investigate the dynamics within public health 
institutions in South Africa (e.g. Chaiyachati, Loveday, Lorenz, Lesh \& Larkan, 2013; Dhai et al., 2011; George, Atujuna \& Gow, 2013; Lehmann \& Gilson, 2013). A number of studies (Appel, 2006; Blaauw et al., 2013; George, Atujuna \& Gow, 2013; Ludy, 2005; Pillay, 2009; Ramasodi, 2010; Visser, McKenzie \& Marais, 2012) concentrated on specific aspects of organisational behaviour amongst public health professionals in various regions of South Africa. The presence of an array of literature focusing on public health sector employees in South Africa provides testimony to the significance of this sector. However, gaps in the literature still exist with regard to the drivers of employee satisfaction and organisational commitment in the public health sector, which gives impetus for further empirical focus on the area.

The current study sought to investigate the relationship between three work-related factors, person-environment fit, work-family balance and perceived job security, and employee satisfaction and organisational commitment amongst health professionals in public health institutions. There is an apparent lack of evidence from studies that examined this combination of relationships in the context of South African public health institutions. In view of this, this study proposes a conceptual framework that is yet to receive prior empirical scrutiny within the South African setting. Additional impetus is provided to investigate the employees' reasons to stay satisfied and committed as public health professionals are of strategic importance to the nation. Therefore, a need exists to extend empirical research evidence that captures the dynamics surrounding the behaviour of public health professionals in South Africa.

\section{Literature review \\ Employee satisfaction}

Researchers vary in their definitions of the concept of employee satisfaction. Employee satisfaction may simply be perceived as the feelings of individuals about their jobs (Arndta, Todd \& Landry, 2006). Sieger, Bernhard and Frey (2011) conceptualise employee satisfaction in terms of how people feel about their jobs and different aspects of their jobs. In support, Ellickson and Logsdon (2002) define employee satisfaction as the extent to which employees like their work. As such, employee satisfaction is an assemblage of factors that depend on the interaction of employees (Fisher, 2000), their individualistic characteristics such as demography, emotions and personality (Cote \& Morgan, 2002), job values and reward expectations such as salary and promotion, environmental factors (Ivancevich \& Matteson, 2005) as well as other factors that may be specific to the unique nature of work being performed such as autonomy, role stress and teamwork (Concha, 2009). For the purposes of this study, the definition by Sieger et al. (2011) was adopted, since it acknowledges that employees' perceptions are not limited to the job only, but they tend to apply to other aspects of the job as well. Therefore, employee satisfaction is a highly complex and multifaceted phenomenon that depends not only on the nature of the job but also on the expectation regarding what that particular job will provide for the employee (Hussami, 2008).
Employee satisfaction leads to a number of consequences to health service employees that include, inter alia, increased productivity (Best, 2008), high-quality care (Al-Aameri, 2000) and intent to remain in the organisation (Yee, Yeung \& Cheng, 2008). These outcomes pose explicit implications for the effectiveness of employees and, ultimately, the performance of the organisation as a whole (Koys, 2001; Mafini \& Pooe, 2013). Additionally, employee satisfaction has been found to be an indicator of constructive employee behavioural traits such as organisational citizenship (Wegge, Schmidt, Parkes \& Van Dick, 2007), withdrawal behavioural traits such as absenteeism and turnover (Saari \& Judge, 2004) as well as desirable behavioural traits such as subservience and orderliness (Mount, Ilies \& Johnson, 2006). It appears then that employee satisfaction is fundamental to the prosperity of both individual employees and the organisation.

\section{Organisational commitment}

Organisational commitment has been defined as a psychological state that characterises an employee's identification, involvement and ultimate relationship with an organisation (Paulina, Fergusona \& Bergeronb, 2006). This factor is characterised by the employee's acceptance of the goals and values of the organisation (identification), the willingness to invest individual effort on behalf of the organisation (involvement) and the importance attached to keeping up the membership in the organisation (loyalty) (Boglera \& Somech, 2004). Research evidence indicates that organisational commitment is negatively related to employee turnover, intention to leave (Cote \& Morgan, 2002; Griffeth, Hom \& Gaertner, 2000) and role stress (Concha, 2009) whilst being positively related to extra-role behaviour, team performance (Lavelle et al., 2009) as well as increased work performance as measured by both self-reported measures and objective measures (Fedor, Caldwell \& Herold, 2006). Within the context of health care, extra job roles include providing extra help to both patients and co-workers (Al-Aameri, 2000; Yoon \& Suh, 2003), being considerate (Fisher, 2000), volunteering for special activities (Ahmad \& Oranye, 2010) and being proactive when emergencies arise at the hospital (Coyle-Shapiro \& Morrow, 2006).

\section{Person-environment fit}

Kristof-Brown, Zimmerman and Johnson (2005) define person-environment fit as the extent to which individual and environmental characteristics match. In other words, person-environment fit may be conceptualised in terms of specific person-situation relations that spell out the equivalence between person and environment dimensions (Ostroff \& Schulte, 2007). Examples of person characteristics include, inter alia, an individual's biological or psychological needs, values, goals, abilities or personality. Similarly, environmental characteristics may consist of job demands, cultural values, rewards or various environmental conditions such as shelter, heat and the availability of food (Cable \& Edwards, 2004). This dimension is characterised by three identifiable domains, namely: person-job fit, person-group fit and person-person fit (Song \& Chon, 2012). 
In addition, antecedents of the person-environment fit comprise of effective performance management (Boon \& Den Hartog, 2011) as well as effective employee attraction. Moreover, noticeable improvements have been chronicled in terms of recruitment, selection, retention as well as training and development processes in various organisations (Chatman, 2011; Kristof-Brown \& Guay, 2011).

\section{Work-family balance}

Although the job-holder and organisational member roles are two important roles, non-work roles (e.g. spouse, family, leisure) have also emerged as an integral part of employees' lives (Allen, Herst, Bruck \& Sutton, 2000). Work-family balance occurs when work life is synchronised with family life such that there is an absence of conflict between these two dimensions of an employee's life (Cinamon, Rich \& Westman, 2007). According to Judge, Ilies and Scott (2006), work-family balance is defeated when work interferes with family such that the paid work role obstructs the fulfilment of roles in the family domain. In addition, when the family roles and duties of an individual interfere greatly to such an extent that the family roles obstruct role fulfilment in the work domain, conflict is inevitable (Subramaniam \& Mia, 2003). Eby, Casper, Lockwood, Bordeaux and Brinley (2005) classify the antecedents of work-family balance into three aspects: work domain variables, non-work domain variables and individual as well as demographic variables. On the other hand, work-family balance acts as an index of a number of positive consequences such as satisfaction amongst employees, increased organisational commitment, decreased turnover as well as reduced intention to quit and occupational stress (Ford, Heinen \& Langkamer, 2007). Work-family balance is highly significant within the health care sector since it largely affects medical professionals who work abnormal hours (shifts) that infringe on their vacation, family and leisure periods.

\section{Perceived job security}

Perceived job security may be defined as a set of subjective feelings about the future security of an individual's employment situation (Fullerton \& Wallace, 2007). Clark, Knabe and Rätzel (2010) state that perceived job security exists when an individual remains employed with the same organisation with no diminution of seniority, pay, pension rights and other associated privileges. Van Praag and Ferrer-i-Carbonell (2008) further argue that job security occurs when an organisation provides stable employment for employees. Employee perceptions of job security are influenced by factors such as education, work experience, job functional area, work industry and work location, all of which perform an important role in determining the need for an individual's services in the public sector (Khan \& Rehnberg, 2009). In contrast, low perceptions of job security may result from factors such as anxiety emanating from one's contemplation of the possibility of losing a job, high levels of exposure to various types of work hazards, loss of job control and decreased workplace social support (Benach, Amable, Muntaner \& Benavides, 2002).

\section{Proposed conceptual framework and hypothesis formulation}

The preceding discussion of the literature led to the formulation of the conceptual framework illustrated in Figure 1. The conceptual framework outlines the effects of specific work-related variables that comprise of the person element (person-environment fit), situational element (work-family balance) as well as an organisational element (perceived job security). The model assumes that the three identified work-related factors are positively associated with employee satisfaction. In turn, employee satisfaction is taken to be positively related to organisational commitment.

\section{Person-environment fit and employee satisfaction}

The person-job match is an important factor when determining the level of satisfaction amongst employees. Based on Pervin's (1968, p. 56) theory on best-fit between an individual and the employing organisation, 'a lack of fit often results in decreased performance, dissatisfaction and stress in the system'. As such, poor person-environment fit has been shown to result in a greater likelihood of undesirable organisational outcomes such as staff turnover and ineffectiveness amongst public hospital employees (Kristof-Brown \& Guay, 2011). Boon and Den Hartog (2011) found person-environment fit to be a mediator variable between organisational trust and employee satisfaction. As such, it may be expected that when a match exists between individual characteristics, the environment and the organisation, both performance and satisfaction tend to be high and employee stress will decrease (Andrews, Baker \& Hunt, 2011). In addition, a study conducted by Gregory, Albritton and Osmonbekov (2010) concluded that there is a significant positive relationship between person-environment fit and employee satisfaction. Drawing from the aforementioned empirical evidence, the following hypothesis is proposed:

- Hypothesis 1: There is a positive association and a predictive relationship between person-environment fit and employee satisfaction.

\section{Work-family balance and employee satisfaction}

Allen et al. (2000) suggest that a balance is necessary in order to foster affective feelings associated with staying happy on

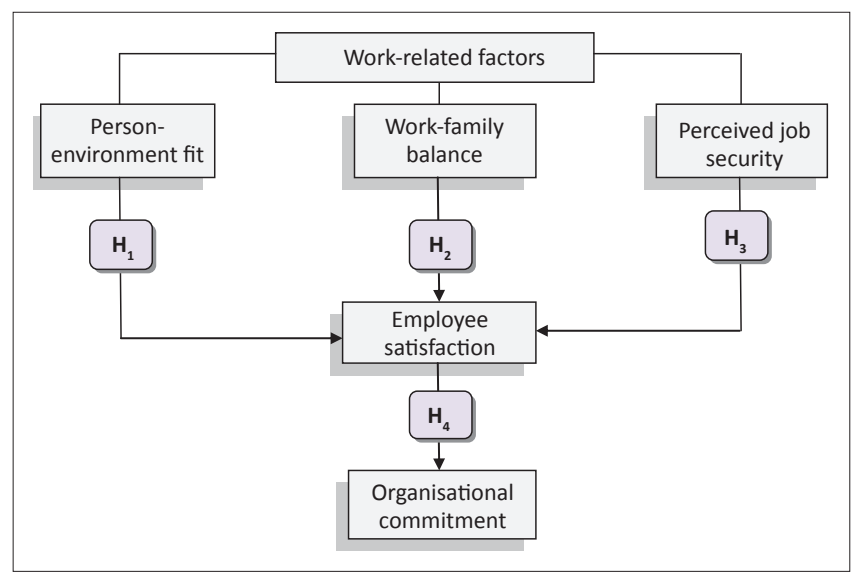

Source: Authors' own conceptual framework

$\mathrm{H}_{1}$, Hypothesis $1 ; \mathrm{H}_{2}$, Hypothesis 2; $\mathrm{H}_{3}$, Hypothesis $3 ; \mathrm{H}_{4}$, Hypothesis 4. FIGURE 1: Conceptual framework. 
the job. Furthermore, a balanced lifestyle is evidenced by the absence of time competition between family and work roles as well as the absence of strain associated with performing roles in both the family and work domains (Hoobler, Wayne \& Lemmon, 2009). Such balance also exists in the absence of behaviour-based conflict associated with incompatible roles (Byron, 2005). Employees who struggle to find balance between their work and family time are likely to experience either work-family conflict or job dissatisfaction (Ford et al., 2007). In contrast, employees who easily find greater balance between their work, family and job schedules are likely to experience the pleasure of both pleasant work environments and valuable family time or obligations (Reynolds, 2005). It could be expected then that work-family balance and employee satisfaction amongst health professionals are positively related. This leads to the following hypothesis:

- Hypothesis 2: There is a positive association and a predictive relationship between employee satisfaction and work-family balance.

\section{Perceived job security and employee satisfaction}

In both developing and developed countries, it has been found that perceptions of job security are higher in government jobs, education and health-care sectors whilst they are expected to be lower in private sector jobs since the latter favour the use of flexible resources (Turnley, Bolino, Lester \& Bloodgood, 2003). Van Praag and Ferrer-i-Carbonell (2008) suggest that temporary staff have a different psychological contract with the organisation than their permanent counterparts. It is also argued that the former will have a transactional contract, with the emphasis on the economic elements of the contract such as a salary, whilst permanent staff will have a more relational contract, involving commitment to the organisation and an interest in a satisfying job (Yea, Cardon \& Rivera, 2012). Furthermore, perceived job security is also influenced by the possession of the necessary skills and experience that are in demand by employers, which in turn depend on the prevailing economic conditions and business environment (Khan \& Rehnberg, 2009). It is an important supposition then that individuals whose services are in demand by employers are likely to enjoy higher perceived job security. Based on the foregoing empirical evidence, the following hypothesis is put forward:

- Hypothesis 3: There is a positive association and a predictive relationship between perceived job security and employee satisfaction.

\section{Employee satisfaction and organisational commitment}

Positive associations have been observed between employee satisfaction and organisational commitment in a number of previous studies (Al-Aameri, 2000; DeWitte \&Na“swall,2003). Research further indicates that organisational commitment is associated with a number of variables such as leadership (Hussami, 2008), job stress (Concha, 2009), organisational justice and fair procedures (Paulina et al., 2006). Interestingly, the aforementioned variables are also known to be significant antecedents of employee satisfaction. A study by Lumley, Coetzee, Tladinyane and Ferreira (2011) found positive and significant relationships between employee satisfaction and organisational commitment. This demonstrates that as the degree of employee satisfaction increases, commitment to the employing organisation is also expected to increase. It is logical then to anticipate a positive association and a predictive relationship between employee satisfaction and organisational commitment amongst health professionals in South Africa. This notion is encapsulated in the following hypothesis:

- Hypothesis 4: There is a positive association and predictive relationship between employee satisfaction and organisational commitment.

\section{Method}

\section{Measures}

\section{Design}

Quantitative research designs have been used in a number of previous studies (Ahmad \& Oranye, 2010; Bagtasos, 2011; Saari \& Judge, 2004) that examined the relationship between various behavioural constructs amongst health professionals. On that basis, a quantitative design using the survey approach was adopted for the present study. The survey method was deemed appropriate for this study because it facilitates ease of data collection from large populations, making it easier to develop and administer the research questionnaire whilst allowing for generalisation of the research findings (Malhotra, 2010).

\section{Sample selection and participants}

A total of 500 survey questionnaires were distributed to respondents who were recruited from three public hospitals in Gauteng, South Africa, using the stratified probability sampling technique. Stratified sampling assumes that the data is normal and ensures that all the population elements have an equal chance of being selected (Iacobucci \& Churchill, 2010). The rationale behind the adoption of a stratified technique was to obtain a balanced distribution of responses from a cross-section of public health professionals. Hospital databases containing information on the job positions of the professionals formed the basis for sampling strata. This culminated in a five-level stratum: (1) administrative employees, (2) technicians, (3) nurses (certified or registered), (4) general practitioners (medical doctors) and (5) specialists (clinical managers, surgeons, dieticians and physicians included).

The sample size was determined using Zikmund and Babin's (2009) historical evidence approach, which uses previous related literature sources (in this case, Ahmad \& Oranye, 2010; Ramasodi, 2010; Siew, Chitpakdee \& Chontawan, 2011) as a nominal anchor. In addition, Green's (1991) rule of thumb was also considered; this prescribes that no less than 50 participants are suitable for multivariate analysis, with the 
number increasing in line with larger numbers of independent variables. Furthermore, the inclusion-exclusion criterion was also adhered to as only public health professionals who were 18 years and older and who had been working at any of the three hospitals for periods not less than 1 year on a full-time basis were included in the sample.

\section{Measuring instruments}

A six-section multidimensional questionnaire that was adapted from previous studies was employed. Section A determined the demographic profile of the participants. Questions in section A were structured on dichotomous, multiple choice and rank-order closed-ended scales. Section B contained questions on person-environment fit and included items that were adapted from Kristof-Brown (1996) as well as the categorical elements that were included under Pervin's (1968) theory on individual-organisation best-fit. In section C, items adapted from studies conducted by Greenhaus and Beutell (1985) and Hofman and Woehr (2006) were used to elicit information on work-family balance. Section D was composed of job security items that were adapted from Buitendach and De Witte (2005) as well as De Cuyper, Notelaers and De Witte (2009). Section E was an adapted version of the Minnesota satisfaction questionnaire, originally designed by Spector (1985). Section F contained questions on organisational commitment that were based on Mowday, Steers and Porter's (1979) organisational commitment questionnaire. The questions in sections B-F were placed on seven-point Likert scales ranging from 1 (strongly disagree) to 7 (strongly agree). All items were scored such that a higher score indicated higher standing on the construct being measured.

\section{Data collection procedures}

The data used in the current study was collected between January and March 2013. Prior to data collection, ethical clearance was granted by the Gauteng provincial health department (authorisation number 2013/07/13-4GPHD). To ensure randomisation, data was collected at different times and days of the week at each of the three public health institutions. During the collection of data, various ethical considerations such as informed consent, the participants' right to anonymity and confidentiality were observed. In addition, voluntary participation was encouraged and the respondents were informed that they were able to withdraw from the study at any stage, if they wished to do so. Of the 500 questionnaires that were distributed, 287 were returned and considered usable for the current study, giving a $57 \%$ response rate.

\section{Reliability and validity of the study}

In this study, it was accepted that assessing the validity and reliability of measuring instruments is integral in validating an instrument's usefulness, as suggested by Alumran, Hou and Hurst (2012). Cronbach's alpha values for the sub-scales were as follows: work-family balance $(\alpha=0.762)$, person-environment fit ( $\alpha=0.805)$, perceived job security
( $\alpha=0.896)$, employee satisfaction $(\alpha=0.884)$ and organisational commitment $(\alpha=0.817)$, which indicate adequate reliability of the sub-scales (Nunnally \& Bernstein, 1994). The Cronbach's alpha coefficient for the entire scale was 0.827 , which confirms the proficiency of the instrument in effectively capturing the constructs examined in the study.

Content and face validity of the instrument were ascertained through pilot testing of the questionnaire with a convenient sample of 50 public health professionals. This procedure was conducted to validate the content of the questionnaire in terms of relevance, accuracy and wording. In addition, the questionnaire was also reviewed by three academics who are experts in the field of organisational behaviour. Feedback from the pilot study and the panel of experts ensured that the instrument only comprised those questions that would validly capture the aims of the study.

Discriminant validity was assessed using the exploratory factor analysis procedure. It was necessary to ascertain the discriminant validity since the proposed conceptual framework had not been tested previously. The aim was to establish whether the set of latent variables on the questionnaire were specifically measuring each construct related to the conceptual model. The results indicated that there were no cross loadings (items loading on one factor only) amongst the constructs included in the framework. In addition, there were no cross loadings on the employee satisfaction (mediator) and organisational commitment (dependent variable) constructs, which confirmed the adequacy of discriminant validity in the scale.

Convergent validity of the study was assessed in two ways. Firstly, the high Cronbach's alpha coefficients for the scale $(\geq 0.70)$ reflect the degree of cohesiveness amongst the variables, thereby serving as an indirect indicator of convergent validity (Nunnaly \& Bernstein, 1994). Secondly, Pearson correlation coefficients indicate the high degree of convergence amongst the constructs linked in the conceptual model. Moreover, predictive validity was assessed using regression analysis. Two of the three independent constructs were statistically significant, which attests to the acceptable predictive validity of the study.

\section{Analysis}

Data was analysed using the Statistical Package for the Social Sciences (SPSS version 21.0). Initially, demographic data of the subjects, frequencies and the scores of the overall workrelated factors as well as measures of central tendency were established. Internal consistency estimates were formulated using Cronbach's alpha coefficients. Following this, a series of multivariate statistical procedures that included exploratory factor analysis, Pearson correlation analysis and linear regression were computed on all the variables. These statistical analysis tools were applied in line with the proposed framework (Figure 1) and were therefore the basis for testing the hypotheses. The required level of significance (p) was set at 0.01 . 


\section{Results}

\section{Sample composition}

The demographic profile of the respondents is reported in Table 1.

Of the respondents, $64 \%(n=184)$ were male whilst $36 \%$ $(n=103)$ were female. The majority of the respondents were aged between 31 and 40 years $(46 \% ; n=133)$. Approximately $47 \%(n=135)$ of the respondents had been employed in public health institutions for periods ranging between 5 and 10 years. With regard to ethnicity, the majority of the respondents were of African descent $(72 \% ; n=207)$, which is representative of the racial composition amongst employees at most public health institutions in South Africa. In terms of job positions, most respondents were either nurses (47\%; $n=134)$; technicians $(25 \% ; n=73)$ or administrative personnel and general employees $(19 \% ; n=56)$. Higher-level medical employees such as medical practitioners $(7 \% ; n=19)$ as well as surgeons, physicians or specialists $(2 \% ; n=5)$ remained in the minority. In addition, most of the respondents $(67 \% ; n=191)$ were permanently employed.

\section{Extraction of work-related factors}

In the study, exploratory factor analysis using the principal components analysis method and Varimax rotation was applied in order to identify the underlying dimensions. An iterative scale purification and refinement procedure was applied during which low factor loadings, cross loadings and low communalities were eliminated with a view to enhancing 'interpretability of the factor structure' (Malhotra, 2010, p. 643). A minimum cut-off of 0.50 was used on the variable loadings. This is consistent with Hair et al.'s (2010) suggestion that factor loadings greater than \pm 0.30 are considered to meet the minimum levels, loadings of \pm 0.40 are considered important and loadings of \pm 0.50 and greater are considered more important (also see Mafini \& Dlodlo 2014).

The Bartlett's test was significant at less than 0.000, inferring that the data set is not an identity matrix with zero correlations (i.e. variables are correlated). Furthermore, the Bartlett's test produced a Chi-square value $\left(\chi^{2}\right)$ of 6728.079 and a Kaiser-Meyer-Olkin (KMO) value of 0.782 (> 0.50), further confirming the suitability of the data set for factor analysis. The total variance explained by the extracted factors was $66.3 \%$, indicating that the other $33.7 \%$ is accounted for by extraneous variables that do not constitute part of this study. The results of the rotated component matrix, percentage of variance explained by each factor, cumulative percentage of variance, eigenvalue criterion and scree plot were assessed. Finally, a three-factor structure was developed and the identified constructs were labelled as perceived job security, person-environment fit or work-family balance, which confirms the structure of the conceptual framework that is presented in this study. Table 2 reports these findings (also see Mafini \& Dlodlo 2014).
TABLE 1: Demographic profile of the respondents.

\begin{tabular}{|c|c|c|c|}
\hline Variable & Categories & $n$ & $\%$ \\
\hline \multirow[t]{2}{*}{ Gender } & Male & 184 & 64 \\
\hline & Female & 103 & 36 \\
\hline \multirow[t]{4}{*}{ Age } & $21-30$ years & 106 & 37 \\
\hline & $31-40$ years & 133 & 46 \\
\hline & $41-50$ years & 37 & 13 \\
\hline & Older than 50 years & 11 & 4 \\
\hline \multirow[t]{4}{*}{ Race or ethnicity } & African & 207 & 72 \\
\hline & White & 23 & 8 \\
\hline & Indian or Asian & 49 & 17 \\
\hline & Mixed race & 8 & 3 \\
\hline \multirow[t]{5}{*}{ Job position } & Specialist & 5 & 2 \\
\hline & General practitioner (MD) & 19 & 7 \\
\hline & Nurse (certified or registered) & 134 & 47 \\
\hline & Technicians & 73 & 25 \\
\hline & Administrative personnel & 56 & 19 \\
\hline \multirow[t]{4}{*}{ Length of service } & $0-5$ years & 46 & 16 \\
\hline & $5-10$ years & 135 & 47 \\
\hline & $10-15$ years & 69 & 24 \\
\hline & More than 15 years & 37 & 13 \\
\hline \multirow[t]{2}{*}{ Form of employment } & Permanent & 191 & 67 \\
\hline & Contract & 96 & 33 \\
\hline
\end{tabular}

$N=287$.

MD, Medical Doctor.

\section{Mean score rankings and standard deviations of factors}

Table 3 reveals the mean score rankings, which were computed with a view to providing a rating of the factors in terms of the level of importance. The minimum and maximum values are based on the lowest and highest values on a seven-point Likert scale. The means were calculated by summating the response values of variables that comprised each dimension divided by the number of variables in each dimension.

The findings of the study revealed that employee satisfaction $(\bar{x}=5.689 ; \mathrm{SD}=3.149)$ and organisational commitment $(\bar{x}=5.567 ; \mathrm{SD}=4.401)$ had the highest mean score rankings in the overall scale. However, in terms of the identified work-related constructs, perceived job security was rated the most important dimension $(\bar{x}=5.331$; $\mathrm{SD}=6.052)$ followed closely by person-environment fit $(\bar{x}=5.226$; SD $=4.585)$. Work-family balance $(\bar{x}=5.069 ; \mathrm{SD}=2.523)$ scored the lowest mean of the identified factors. These findings reveal that all three work-based dimensions are moderately important in contributing towards the employee satisfaction of public service health employees.

\section{Correlation and regression analyses}

Pearson correlations were computed in order to identify significant relationships between the three work-related factors and employee satisfaction as well as between employee satisfaction and organisational commitment. The results are reported in Table 4.

Since the relationship between the identified work-related factors and employee satisfaction showed significant positive correlations, it was necessary to conduct regression analysis 
TABLE 2: Extracted work-related factors, employee satisfaction, organisational commitment and description of dimensions.

\begin{tabular}{|c|c|c|c|c|}
\hline Factor & Label & $\begin{array}{l}\text { Number of } \\
\text { items }\end{array}$ & $\begin{array}{l}\text { Percentage } \\
\text { variance explained }\end{array}$ & Eigenvalue \\
\hline 1 & $\begin{array}{l}\text { Organisational } \\
\text { commitment }\end{array}$ & 5 & 32.875 & 8.502 \\
\hline 2 & $\begin{array}{l}\text { Employee } \\
\text { satisfaction }\end{array}$ & 8 & 5.149 & 2.914 \\
\hline 3 & $\begin{array}{l}\text { Person-environment } \\
\text { fit }\end{array}$ & 4 & 5.120 & 1.809 \\
\hline 4 & Work-family balance & 4 & 4.298 & 1.230 \\
\hline 5 & $\begin{array}{l}\text { Perceived job } \\
\text { security }\end{array}$ & 6 & 3.710 & 1.169 \\
\hline \multicolumn{5}{|c|}{$\begin{array}{l}\text { Note: Please see the full reference list of the article, Mafini, C., \& Dlodlo, N. (2014). The I } \\
\text { from public health professionals. SA Journal of Human Resource Management/SA Tydskrif } \\
\text { for more information. }\end{array}$} \\
\hline \multicolumn{5}{|c|}{$\begin{array}{l}\text { TABLE 3: Mean score rankings of the work-related factors, employee satisfactio } \\
\text { and organisational commitment. }\end{array}$} \\
\hline \multicolumn{2}{|c|}{ Dimension or construct } & $\begin{array}{l}\text { Mean score } \\
\text { ranking }\end{array}$ & $\begin{array}{l}\text { Mean factor } \\
\text { score }(\bar{x})\end{array}$ & $\begin{array}{l}\text { Standard } \\
\text { deviation }\end{array}$ \\
\hline \multicolumn{2}{|c|}{ Employee satisfaction } & 1 & 5.689 & 3.149 \\
\hline \multicolumn{2}{|c|}{ Organisational commitment } & 2 & 5.567 & 4.401 \\
\hline \multicolumn{2}{|c|}{ Perceived job security } & 3 & 5.331 & 6.052 \\
\hline \multicolumn{2}{|c|}{ Person-environment fit } & 4 & 5.226 & 4.585 \\
\hline \multicolumn{2}{|c|}{ Work-family balance } & 5 & 5.069 & 2.523 \\
\hline
\end{tabular}

Minimum mean value $=1$ Maximum mean value $=7$

$N=287$.

in order to test causality. As a preliminary procedure, the correlation matrix was examined for the existence of multicollinearity, that is, if the predictor variables correlate too highly $(r>0.9)$ with each other (Field, 2005). Since none of the correlations in Table 4 reached a value of greater than 0.9 , the data was considered suitable for regression analysis. Consequently, the 'enter' method of regression was applied to the data set with a view to ascertaining whether any causal relationships exist between the three work-related factors (independent variables) and employee satisfaction (dependent variable). Field (2005, p. 349) suggests that if the variance inflation factor (VIF) is greater than 10, it implies that the predictor variables are correlated amongst themselves, which makes collinearity a cause for concern. The VIF for the three sub-scales in the current study ranged between 1.615 and 2.021, which implies that multicollinearity was not a problem for the current study. The $F$ statistic obtained was 56.849 with 4 degrees of freedom $(d f)$. The results are reported in Table 5.

The regression analysis results revealed that the three sub-scales had an adjusted $R^{2}$ value of 0.412 , implying that the independent variables explain approximately $41 \%$ of the total variance in employee satisfaction. The other 59\% of variability of employee satisfaction can be explained by other factors (non-work-related) that were not explored in this study. Employee satisfaction was strongly predicted by person-environment fit and perceived job security. Beta values showed perceived job security was the strongest predictor $(\beta=0.184 ; t=2.235 ; p<0.01)$, followed by person-environment fit $(\beta=0.064 ; t=1.722 ; p<0.05)$. An interesting result is the negative and insignificant predictive relationship $(\beta=-0.268 ; t=-1.159 ; p>0.05)$ between work-family balance and employee satisfaction.

The proposed relationship between employee satisfaction and organisational commitment was tested through regression analysis. Employee satisfaction was entered into the regression model as the independent variable whilst organisational commitment was entered as the dependent variable. The findings are reported in Table 6.

As shown in Table 6, employee satisfaction explained approximately $24.1 \%\left(R^{2}=0.241\right)$ of the variation of organisational commitment amongst health professionals. Collinearity statistics showed a tolerance value of 0.604 (tolerance $>0.50$ ) as well as a VIF value of 3.492 $(1.0 \leq$ VIF $\leq 10.0)$, thus attesting to the insignificance of the multicollinearity problem within the regression model.

\section{Discussion}

\section{Person-environment fit and employee satisfaction}

A strong positive association was observed between person-environment fit and employee satisfaction $(r=0.569$; $p<0.05)$. The person-environment fit factor also emerged as a statistically significant predictor of employee satisfaction $(\beta=0.064 ; t=1.722 ; p=0.048)$ in the regression analysis. These findings demonstrate that the employee satisfaction of public health employees increases or decreases in parallel to the degree of person-environment fit. In addition, the degree of person-environment fit reflects the extent to which health professionals are satisfied at work.

In line with the abovementioned results, it is widely acknowledged that person-environment fit influences a number of organisational outcomes, all of which are also related to employee satisfaction in one way or another (Kristof-Brown, Zimmerman \& Johnson, 2005). Consequently, employees tend to feel a greater sense of accomplishment, receive more positive evaluations from supervisors and obtain more tangible rewards such as pay increases, promotions and increased responsibility (Scroggins, 2007). In turn, these rewards serve to reinforce desirable values and behaviour amongst employees (Song \& Chon, 2012). A number of previous scholars (Hofman \& Woehr, 2006; KristofBrown, Barrick \& Stevens, 2005) found consistent positive relationships between person-environment fit and important workplace attitudes and behaviour such as employee 
TABLE 4: Correlation analysis - extracted work-related factors, employee satisfaction and organisational commitment.

\begin{tabular}{lcccc}
\hline Construct or dimension & PEF & WFB & PJS & ES \\
\hline Person-environment fit & 1 & - & - & - \\
Work-family balance & $0.526^{* *}$ & 1 & - & - \\
Perceived job security & $0.273^{* *}$ & $0.035^{*}$ & 1 & - \\
Employee satisfaction & $0.569^{*}$ & $0.182^{*}$ & $0.420^{* *}$ & - \\
Organisational commitment & $0.502^{* *}$ & $0.111^{*}$ & $0.425^{* *}$ & - \\
\hline
\end{tabular}

PEF, person-environment fit; WFB, work-family balance; PJS, perceived job security; ES, employee satisfaction; OC, organisational commitment.

**, Correlation is significant at the 0.01 level (two-tailed); ${ }^{*}$, correlation is significant at the 0.05 level (two-tailed)

TABLE 5: Regression analysis - work-related factors and employee satisfaction. Independent variables: Work-related factors

\begin{tabular}{ccccc}
\hline \multicolumn{3}{c}{ Dependent variable: Employee satisfaction } \\
\cline { 3 - 4 } Beta & $\boldsymbol{T}$ & Sig. & Collinearity statistics \\
& & & 0.509 & VIF \\
\hline 0.064 & 1.722 & $0.048^{*}$ & 0.582 & 1.963 \\
0.268 & -1.159 & 0.522 & 0.619 & 1.717 \\
0.184 & 2.235 & $0.002^{* *}$ & & 1.615 \\
\hline
\end{tabular}

Sig., significance; VIF, variance inflation factor.

$R=0.706 ;$ Adjusted $R^{2}=0.412 ; F=56.849 ; d f=4$.

**, Correlation is significant at the 0.01 level (two-tailed); ${ }^{*}$, correlation is significant at the 0.05 level (two-tailed)

TABLE 6: Regression model 2 - employee satisfaction and organisational commitment.

\begin{tabular}{|c|c|c|c|c|c|}
\hline \multirow[t]{3}{*}{ Independent variable } & \multicolumn{5}{|c|}{ Dependent variable: Organisational commitment } \\
\hline & \multirow[t]{2}{*}{ Beta } & \multirow[t]{2}{*}{$T$} & \multirow[t]{2}{*}{ Sig. } & \multicolumn{2}{|c|}{ Collinearity statistics } \\
\hline & & & & Tolerance & VIF \\
\hline Employee satisfaction & 0.337 & 5.412 & $0.000 * *$ & 0.604 & 3.492 \\
\hline
\end{tabular}

Sig., significance; VIF, variance inflation factor.

$R=0.491$; Adjusted $R^{2}=0.241 ; F=26.216$

$* *$, Correlation is significant at the 0.01 level (two-tailed)

satisfaction, intentions to leave, career success, in-role performance and citizenship behaviour. A study by KristofBrown and Guay (2011) identifies person-environment fit as one of the strongest predictors of employee satisfaction. An earlier study by Tak (2007) suggests that person-environment fit could explain significant variance in job performance, organisational citizenship behaviour, turnover and employee satisfaction. A meta-analysis by Verquer, Beehr and Wagner (2003) indicates that person-environment fit was related to employee satisfaction and intention to quit amongst nurses. It is not surprising then that there were positive and significant associations between person-environment fit and employee satisfaction in the current study. Hypothesis 1 is therefore supported and is accepted in this study.

\section{Work-family balance and employee satisfaction}

A positive but weak association $(r=0.182 ; p<0.05)$ was observed between work-family balance and employee satisfaction. However, the regression analysis results revealed that work-family balance is not a statistically significant predictor $(\beta=-0.268 ; t=-1.159 ; p=0.522)$ of employee satisfaction. These findings illustrate that work-family balance neither triggers any significant increases in nor predicts the employee satisfaction of public health professionals. The results of the current study contradict the established view that work-family balance is positively linked to employee satisfaction. According to Zhao and Namasivayam (2012), employees who experience high work-family balance have high satisfaction levels, less work-related stress and fewer job resignations. Bloom, Kretschmer and Van Reenen (2006) note that a balance between work and family responsibilities amongst employees has a stimulus effect on employee satisfaction and organisational performance. Conversely, an imbalance between work and family results in reduced employee commitment (McCarthy \& Cleveland, 2005), occupational stress (Darcy \& McCarthy, 2007), decreased employee satisfaction (Poelmans \& Sahibzada, 2004) as well as reduced employee productivity (Grady \& McCarthy, 2008).

The unorthodox result of this study could be attributed to the fact that workers in the health-care profession are expected to work round the clock, due to the life-saving nature of their responsibilities. For instance, doctors can be officially 'on call' for $24 \mathrm{~h}$ a day or called back to work for emergency purposes at any time. Even supporting services such as technicians and administration staff work odd hours to provide full service to patients. Health professionals are also expected to be on duty during periods that are normally designated as family time (Baldwin \& Daugherty, 2004; Brown et al., 2010). It is possible that when employees are expected to report for duty at any hour, the balance of work and family ceases to be a compelling issue. This is in contrast to professionals in other work disciplines, who work under different job environments. It can be deducted then that although work-family balance is positively associated with employee satisfaction, the relationship between the two factors amongst health professionals in South Africa is weak and insignificant. Based on these findings, hypothesis 2 is partially accepted in this study and may be considered for further study in future empirical studies. 


\section{Perceived job security and employee satisfaction}

With regard to employee perceptions of job security, a positive and moderate association $(r=0.420 ; p<0.01)$ was observed between perceived job security and employee satisfaction. In the regression analysis, perceived job security emerged as a statistically significant predictor $(\beta=0.184$; $t=2.235 ; p=0.002$ ) of employee satisfaction. These findings disclose that the satisfaction of public health employees increases in line with their perceptions of the level of job security. Additionally, the perceived job security of public health professionals serves as an index of their satisfaction at work. These results are in line with previous studies by Dawley, Andrews and Bucklew (2008) and Yea et al. (2012) in which similar conclusions were made. Smith (2010) found that job security is related to employee satisfaction through reduced intention to quit and lower staff turnover. A study by Sverke and Goslinga (2003) that focused on health professionals from a number of European countries reveals that a reduction in job security leads to a corresponding decline in satisfaction. Another study by De Witte and Na"Swall (2003) concludes that there is a positive association between job security and both organisational commitment and employee satisfaction. In a number of previous studies (Domenighetti, D’Avanzo \& Bisig, 2000; McDonough, 2000; Probst, 2002), it was found that individuals who had high levels of job security were in good health and experienced lower levels of workplace injuries and accidents, leading to high satisfaction levels. Ferrie, Shipley, Newman, Stansfeld and Marmot (2005) further opine that job security stimulates improved physical and emotional health amongst health-care employees. Still, high perception levels of job security are associated with organisational effectiveness, which is also linked to employee satisfaction (De Witte \& Na“Swall, 2003). The literature cited in this discourse tends to add credence to the findings of the current study. Therefore, hypothesis 3 is supported and is accepted in this study.

\section{Employee satisfaction and organisational commitment}

An analysis of the correlation matrix (Table 4) indicates a strong positive association $(r=0.686 ; p=0.01)$ between employee satisfaction and organisational commitment. A further analysis of the regression model (Table 6) reveals that employee satisfaction is a significant predictor $(\beta=0.337$; $t=5.412 ; p=0.000$ ) of organisational commitment. The results of the correlation analysis demonstrate that an increase in the employee satisfaction of public health professionals leads to an increase in their levels of commitment and vice versa. The result of the regression analysis illustrates that the employee satisfaction of public health professionals is an indicator of their degree of organisational commitment. These results are consistent with previous studies (Al-Aameri, 2000; Siew et al., 2011; Tsai \& Huang, 2007) in which employee satisfaction was found to be related to organisational commitment amongst various health professionals. A metaanalysis by Meyer, Stanley, Herscovitch and Laryssa (2002) also shows that that there is a strong positive relationship between employee satisfaction and organisational commitment.
A number of scholars (Griffeth et al., 2000; Martensen \& Gronholdt, 2001) have found direct predictive interactions between employee satisfaction and organisational commitment. Satisfied employees are more likely to exert more effort in their work and provide better services through organisational citizenship behaviour, which attests to their commitment (Hom \& Kinicki, 2001; Yoon \& Suh, 2003). Studies by Rahman and Bullock (2005) and Juna, Caib and Shinc (2006) also conclude that employee satisfaction is arguably the most important determinant of employee commitment to their organisations. Yee et al. (2008) found that satisfied employees tend to be more involved in their organisations and demonstrate more dedication towards the delivery of high-quality services. Moreover, employee satisfaction leads to client (patient) satisfaction, mainly because satisfied employees are more likely to be motivated and work harder than dissatisfied ones (Chi \& Gursoy, 2009). It is logical then to conclude that the satisfaction of public health professionals is deeply intertwined with their organisational commitment. Based on these findings, hypothesis 4 is accepted in this study.

\section{Strengths, limitations and implications for future research}

The strength of this study lies in the use of a stratified sample, which presented the study with valid findings that are based on a cross-section of the target population. In addition, data was collected from three public health institutions, rather than a single one, which further enhances the validity of the current study. However, the findings of the study are limited in that they are restricted to only 287 participants who were based in Gauteng. This has the potential of limiting the extent to which the findings can be generalised to other contexts. A possible remedy then could be to replicate the study in other provinces. The study is further limited in that it is based on only three work-related factors when it is known that there are other significant factors that may be extended to the current framework. In view of this fact, future studies could focus on these work-related factors as well as other non-workrelated constructs that did not form part of this study. In addition, the proposed conceptual framework could further be tested using more robust statistical applications such as path modeling. Comparative studies of the perspectives of public health professionals and their counterparts in private health institutions could also be conducted.

\section{Conclusion}

The purpose of this study was to examine the relationship between three work-related factors, person-environment fit, work-family balance and perceived job security, and employee satisfaction and organisational commitment amongst health professionals in public health institutions. The results of the correlation analysis revealed that there were strong positive associations between employee satisfaction and two workrelated factors, person-environment fit and perceived job security. The association between work-family balance and employee satisfaction was weak. However, employee satisfaction and organisational commitment were strongly 
correlated. Results of the regression analysis showed that person-environment fit and perceived job security were both statistically significant in predicting employee satisfaction. In turn, employee satisfaction predicted organisational commitment. Work-family balance was insignificant in predicting employee satisfaction.

Based on the aforementioned results, three conclusions can be made. Firstly, the employee satisfaction of public health professionals is strongly related to and is predicted by their levels of person-environment fit as well as perceptions of job security. Secondly, work-family balance, in this case, neither strongly influences nor predicts the employee satisfaction of public health professionals. Thirdly, the commitment of public health professionals to their organisations is strongly associated with and is predicted by the level of employee satisfaction.

\section{Managerial implications}

The results of the current study have managerial implications, which are worth highlighting. These findings could be used as a reference point for managers in public organisations as they seek to enhance the motivation of their workforce, leading to decreased cases of both labour unrest and staff turnover in the sector. More specifically, improvements in the individual factors examined in this study could be made in order to boost the related outcomes. Sustained training and development of health professionals may be necessary in order to continuously augment their levels of person-environment fit. Such actions may facilitate the further improvement of the skills of health professionals so that they may be in sync with the requirements and demands of their jobs, or to prepare them to make the transition into new ones (Boon \& Den Hartog, 2011). It is also necessary to enhance the perceptions of job security amongst professionals in the public health sector. An effective strategy may be to increase the number of permanent job positions within health public institutions. Efforts by management in public health institutions to meet the employment needs of professionals may also promote higher levels of job security. Overall, in order for public health institution management to maintain the morale of professionals, a balance should be maintained amongst all the factors examined in this study with a view to creating a fulfilling working experience.

\section{Acknowledgements Competing interests}

The authors declare that they have no financial or personal relationship(s) that may have inappropriately influenced them in writing this article.

\section{Authors' contributions}

C.M. (Vaal University of Technology) was responsible for the literature review, the research methodology section and made language revisions to the manuscript. N.D. (Vaal University of Technology) performed the data analysis and interpreted the results and wrote the results section up to the conclusion.

\section{References}

Ahmad, N., \& Oranye, N.O. (2010). Empowerment, job satisfaction and organizational commitment: A comparative analysis of nurses working in Malaysia and England. Journal of Nursing Management, 8(5), 582-591. http://dx.doi. org/10.1111/j.1365-2834.2010.01093.x

Al-Aameri, A.S. (2000). Job satisfaction and organizational commitment for nurses. Saudi Medical Journal, 21, 531-535.

Allen, T.D., Herst, D.E., Bruck, C.S., \& Sutton, M. (2000). Consequences associated with work-to-family conflict: A review and agenda for future research. Journal of Occupational Health Psychology, 5(1), 278-308. http://dx.doi.org/10.1037/10768998.5.2.278

Alumran, A., Hou, X., \& Hurst, C. (2012). Validity and reliability of instruments designed to measure factors influencing the overuse of antibiotics. Journal of Infection and Public Health, 5, 221-232. http://dx.doi.org/10.1016/j.jiph.2012.03.003

Andrews, M.C., Baker, T., \& Hunt, T.G. (2011). Values and person-organization fit: Does moral intensity strengthen outcomes? Leadership \& Organization Development Journal, 32(1), 5-19. http://dx.doi.org/10.1108/01437731111099256

Appel, C. (2006). Assessment of job satisfaction of environmental officers within a Gauteng government department. Master's thesis, Faculty of Management Sciences, Tshwane University of Technology, South Africa.

Arndta, A., Todd, J.A., \& Landry, T.D. (2006). The effects of polychronic-orientation upon retail employee satisfaction and turnover. Journal of Retailing, 82(4), 319-330. http://dx.doi.org/10.1016/j.jretai.2006.08.005

Bagtasos, M.R. (2011). Quality of work life: A review of literature. Business and Economics Review, 20(2), 1-8.

Baldwin, D.C., \& Daugherty, S.R. (2004). Sleep deprivation and fatigue in residency training: Results of a national survey of first- and second-year residents. Sleep, 27(2), 217-223.

Benach, J., Amable, M., Muntaner, C., \& Benavides, F. (2002). The consequences of flexible work for health: Are we looking at the right place? Journal of Epidemiology and Community Health, 56(6), 405-406. http://dx.doi.org/10.1136/jech.56.6.405

Best, R. (2008). Employee satisfaction, firm value and firm productivity. Retrieved August 23, 2013, from http://ideas.repec.org/p/umn/wpaper/0806.html

Blaauw, D., Ditlopo, P., Maseko, F., Chirwa, M., Mwisongo, A., Bidwell, P. et al. (2013). Comparing the job satisfaction and intention to leave of different categories of health workers in Tanzania, Malawi, and South Africa. Global Health Action of health workers in
Journal, 24(6), 87-92.

Bloom, N., Kretschmer, T., \& Van Reenen, J. (2006). Work life balance, management practices and productivity. London, UK: London School of Economics.

Boglera, R., \& Somech, A. (2004). Influence of teacher empowerment on teachers' organizational commitment, professional commitment and organizational citizenship behavior in schools. Teaching and Teacher Education, 20(1), 277-289. http://dx.doi.org/10.1016/j.tate.2004.02.003

Boon, C., \& Den Hartog, D.N. (2011). Human resource management, personenvironment fit and trust. In R. Searle \& D. Skinner (Eds.), Trust \& Human Resource Management, (pp. 109-121). Chichester, UK: Edward Elgar. http://dx.doi. org/10.4337/9780857932006.00013

Brown, M., Tucker, P., Rapport, F., Hutchings, H., Dahlgren, A., \& Davies, G. (2010). The impact of shift patterns on junior doctors' perceptions of fatigue, training, 19(6), 36-51.

Buitendach, J.H., \& De Witte, H. (2005). Job insecurity, extrinsic and intrinsic job satisfaction and affective organizational commitment of maintenance workers in a parastatal. South African Journal of Business Management, 36(2), 27-37.

Byron, K. (2005). A meta-analytic review of work-family conflict and its antecedents. Journal of Vocational Behaviour, 67(1), 169-198. http://dx.doi.org/10.1016/j. jvb.2004.08.009

Cable, D.M., \& Edwards, J.R. (2004). Complementary and supplementary fit: A theoretical and empirical integration. Journal of Applied Psychology, 89(1), 822-834. http://dx.doi.org/10.1037/0021-9010.89.5.822

Chaiyachati, K.H., Loveday, M., Lorenz, S., Lesh, N., \& Larkan, L.-M. (2013). A pilot study of health application for healthcare workers: Poor uptake despite high reported acceptability at a rural South African community-based MDR-TB Treatment Program. PLOS ONE, 8(5), 64-68. http://dx.doi.org/10.1371/journal. pone.0064662

Chatman, J. (2011). Matching people and organisations: Selection and socialization in public accounting firms. Administrative Science Quarterly, 36(1), 459-484.

Chi, C.G., \& Gursoy, D. (2009). Employee satisfaction, customer satisfaction, and financial performance: An empirical examination. International Journal of Hospitality Management, 28(1), 245-253. http://dx.doi.org/10.1016/j. of Hospitality

Cinamon, R.G., Rich, Y., \& Westman, M. (2007). Teachers' occupation-specific workfamily conflict. The Career Development Quarterly, 55(1), 249-261. http://dx.doi. org/10.1002/j.2161-0045.2007.tb00081.x

Clark, A., Knabe, A., \& Rätzel, S. (2010). Boone or bane? Others' unemployment, well-being and job insecurity. Labour Economics, 17(1), 52-61. http://dx.doi. org/10.1016/j.labeco.2009.05.007

Concha, A. (2009). The impact of role stress on workers' behaviour through job satisfaction and organisational commitment. International Journal of Psychology, 44(3), 187-194.http://dx.doi.org/10.1080/00207590701700511 
Cote, S., \& Morgan, L.M. (2002). A longitudinal analysis of the association between emotion regulation, job satisfaction, and intentions to quit. Journal of emotion regulation, job satisfaction, and intentions to quit. Journal
Organizational Behavior, 23(1), 947-962. http://dx.doi.org/10.1002/job.174

Coyle-Shapiro, J.A.M., \& Morrow, P.C. (2006). Organizational and client commitment among contracted commitment among contracted employees. Journal of Vocational Behavior, 63, 416-431. http://dx.doi.org/10.1016/j.jvb.2005.10.002

Darcy, C., \& McCarthy, A. (2007). Work family conflict: An exploration of the differential effects of a dependent child's age on working parents. Journal of European Industrial Training, 31(7), 64-79. http://dx.doi.org/10.1108/03090590710820042

Dawley, D.D., Andrews, M.C., \& Bucklew, N.S. (2008). Mentoring, superviso support and perceived organizational support: What matters most? Leadership and Organization Development Journal, 29(1), 235-247. http://dx.doi. org $/ 10.1108 / 01437730810861290$

De Cuyper, N., Notelaers, G., \& De Witte, H. (2009). Job insecurity and employability in fixed-term contractors, agency workers, and permanent workers: Association with job satisfaction and affective organizational commitment. Journal of Occupational Health Psychology, 14(2), 193-205. http://dx.doi.org/10.1037/ a0014603

De Witte, H., \& Na"Swall, K. (2003). Objective versus subjective job insecurity Consequences of temporary work for job satisfaction and organisational commitment in four European countries. Economic and Industrial Democracy, 24(1), 149-188. http://dx.doi.org/10.1177/0143831X03024002002

Dhai, A., Etheredge, H.R., Vorster, M., \& Veriava Y. (2011). The public's attitude towards strike action by healthcare workers and health services in South Africa. South African Journal of Bioethics and Law, 4(2), 58-62.

Domenighetti, G., D'Avanzo, B., \& Bisig, B. (2000). Health effects of job insecurity among employees in the Swiss general population. International Journal of Healt Services, 30(3), 477-490. http://dx.doi.org/10.2190/B1KM-VGN7-50GF-8XJ4

Eby, L.T., Casper, W.J., Lockwood, A., Bordeaux, C., \& Brinley, A. (2005). Work and family research in IO/OB: Content analysis and review of the literature (1980-2002). Journal of Vocational Behavior, 66, 124-197. http://dx.doi. org/10.1016/j.jvb.2003.11.003

Ellickson, M.C., \& Logsdon, K. (2002). Determinants of job satisfaction of municipal government employees. State and Local Government Review, 33(1), 173-184.

Fedor, D.B., Caldwell, S., \& Herold, D.M. (2006). The effects of organizational changes on employee commitment: A multilevel investigation. Personnel Psychology, 59, 1-29. http://dx.doi.org/10.1111/j.1744-6570.2006.00852.x

Ferrie, J.E., Shipley, M.J., Newman, K., Stansfeld, S.A., \& Marmot, M. (2005). Selfreported job insecurity and health in the Whitehall II study: Potential explanation of the relationship. Social Science and Medicine, 60(1), 1593-1602. http://dx.doi. org/10.1016/j.socscimed.2004.08.006

Field, A. (2005). Discovering statistics using SPSS. (2nd edn.). London, UK: Sage Publishers.

Fisher, D. (2000). Mood and emotions while working: Missing pieces of job satisfaction? Journal of Organizational Behavior, 21(1), 185-202. http://dx.doi. org/10.1002/(SICI)1099-1379(200003)21:2<185::AID-JOB34>3.0.CO;2-M

Ford, M.T., Heinen, B.A., \& Langkamer, K.L. (2007). Work and family satisfaction and conflict: A meta-analysis of cross-domain relations. Journal of Applied Psychology, 92(1), 57-80. http://dx.doi.org/10.1037/0021-9010.92.1.57

Fullerton, A.S., \& Wallace, M. (2007). Traversing the flexible turn: US workers' perceptions of job security, 1977-2002. Social Science Research, 36(1), 201-221. $\mathrm{http}: / / \mathrm{dx}$.doi.org/10.1016/j.ssresearch.2005.09.005

George, G., Atujuna, M., \& Gow, J. (2013). Migration of South African health workers: The extent to which financial considerations influence internal flows and external movements. BMC Health Services Research, 13(1), 297-310. http://dx.doi. org/10.1186/1472-6963-13-297

George, G., Gow, J., \& Bachoo, S. (2013). Understanding the factors influencing healthworker employment decisions in South Africa. Human Resources for Health, 10(1), $11-15$.

Grady, G., \& McCarthy, A. (2008). Work-life integration: Experiences of mid-career professional working mothers. Journal of Managerial Psychology, 23(5), 599-622. professional working mothers. Journal of Manag
$\mathrm{http}: / / \mathrm{dx}$.doi.org/10.1108/02683940810884559

Green, S.B. (1991). How many subjects does it take to do a regression analysis? Multivariate Behavioral Research, 26, 499-510. http://dx.doi.org/10.1207/ s15327906mbr2603 7

Greenhaus, J.H., \& Beutell, N.J. (1985). Sources and conflict between work and family roles. The Academy of Management Review, 10(1), 230-258.

Gregory, B.T., Albritton, M.D., \& Osmonbekov, T. (2010). The mediating role of psychological empowerment on the relationships between $\mathrm{P}-\mathrm{O}$ fit, job satisfaction, and in-role performance. Journal of Business Psychology, 25, 639-647. http://dx.doi.org/10.1007/s10869-010-9156-7

Griffeth, R.W., Hom, P.W., \& Gaertner, S. (2000). A meta-analysis of antecedents and correlates of employee turnover: Update, moderator tests, and research implication for the next millennium. Journal of Management, 26(3), 463-488. http://dx.doi.org/10.1177/014920630002600305

Hair, J.F., Black, B., Babin, B., Anderson, R.E., Tatham, R.L., \& Black, W.C. (2010) Multivariate data analysis: A global perspective. New York, NY: Pearson Education Inc.

Hofman, B.J., \& Woehr, D.J. (2006). A quantitative review of the relationship between person-organisation fit and behavioral outcomes. Journal of Vocational Behavior 68(1), 389-395. http://dx.doi.org/10.1016/j.jvb.2005.08.003

Hom, P.W., \& Kinicki, A.J. (2001). Toward a greater understanding of how dissatisfaction drives employee turnover. Academy of Management Journal, 44(5), 975-987. $\mathrm{http}: / /$ dx.doi.org/10.2307/3069441
Hoobler, J., Wayne, S., \& Lemmon, G. (2009). Bosses' perception of family-work conflict and women's promotability: Glad ceiling effects. Academy of Management conflict and women's promotability: Glad ceiling effects. Academy of Mana
Journal, 52(5), 939-957. http://dx.doi.org/10.5465/AMJ.2009.44633700

Hussami, M. (2008). A study of nurses' job satisfaction: The relationship to organizational commitment, perceived organizational support, transactional leadership, transformational leadership, and level of education. European Journal of Scientific Research, 22(2), 286-295.

lacobucci, D., \& Churchill, G.A. (2010). Marketing research: Methodological foundations. USA: Cengage Southwestern Publishers.

Ivancevich, J.M., \& Matteson, M.T. (2005). Organizational behavior and management. Chicago, IL: Irwin.

Judge, T., Ilies, R., \& Scott, B. (2006). Work-family conflict and emotions: Effects at work and at home. Personnel Psychology, 59, 779-814. http://dx.doi. org/10.1111/j.1744-6570.2006.00054.x

Juna, M., Caib, S., \& Shinc, H. (2006). TQM practice in Maquiladora: Antecedents of employee satisfaction and loyalty. Journal of Operations Management, 24 791-812. http://dx.doi.org/10.1016/j.jom.2005.09.006

Khan, J., \& Rehnberg, C. (2009). Perceived job security and sickness absence: A study on moral hazard. European Journal of Health Economics, 10, 421-428. http:// on moral hazard. European Journal of

Koys, D.J. (2001). The effects of employee satisfaction, organizational citizenship behavior, and turnover on organizational effectiveness: A unit-level, longitudinal study. Personnel Psychology, 54(1), 101-114. http://dx.doi. org/10.1111/j.1744-6570.2001.tb00087.x

Kristof-Brown, A.L. (1996). Person-organization fit: An integrative review of its conceptualisations, measurement and implications. Personnel Psychology, 49(1), 1-49. http://dx.doi.org/10.1111/j.1744-6570.1996.tb01790.x

Kristof-Brown, A.L., Barrick, M., \& Stevens, C.K. (2005). When opposites attract: A multi-sample demonstration of complementary person-team fit on extraversion Journal of Personality, 73, 935-958. http://dx.doi.org/10.1111/j.14676494.2005.00334.x

Kristof-Brown, A.L., \& Guay, R.P. (2011). Person-environment fit. APA Handbook of Industrial and Organizational Psychology, 3, 3-50.

Kristof-Brown, A.L., Zimmerman, R.D., \& Johnson, E.C. (2005). Consequences of individuals' fit at work: A meta-analysis of person-job, person-organization, person-group, and person-supervisor fit. Personnel Psychology, 58, 281-342. http://dx.doi.org/10.1111/j.1744-6570.2005.00672.x

Lavelle, J.J., Brockner, J., Konovsky, M.A., Price, K.H., Henley, A.B., \& Taneja, A. (2009). Commitment, procedural fairness, and organizational citizenship behavior: A multifoci analysis. Journal of Organizational Behavior, 30(1), 337-357. http:// dx.doi.org/10.1002/job.518

Lehmann, U., \& Gilson, L. (2013). Actor interfaces and practices of power in a community health worker programme: A South African study of unintended community health worker programme: A South African study of unintended
policy outcomes. Health Policy Plan, 28(4), 358-366. http://dx.doi.org/10.1093/ policy outcomes.
heapol/czs066

Ludy, N. (2005). Job satisfaction among employees at a public health institution in the Western Cape. Cape Town, South Africa: University of the Western Cape.

Lumley, E.J., Coetzee, M., Tladinyane, R., \& Ferreira, N. (2011). Exploring the job satisfaction and organisational commitment of employees in the information technology environment. Southern African Business Review, 15(1), 100-118.

Mafini, C., \& Dlodlo, N. (2014). The relationship between extrinsic motivation, job satisfaction and life satisfaction amongst employees in a public organisation. SA Journal of Industrial Psychology/SA Tydskrif vir Bedryfsielkunde, 4O(1), Art. \#1166, 13 pages. http://dx.doi.org/10.4102/sajip.v40i1.1166

Mafini, C., \& Pooe, R.I.D. (2013). The relationship between employee satisfaction and organisational performance: Evidence from a South African government department. SA Journal of Industrial Psychology/SA Tydskrif vir Bedryfsielkunde, 39(1), 1041-1090. http://dx.doi.org/10.4102/sajip.v39i1.1090

Malhotra, N.K. (2010). Marketing research: An applied orientation. Eaglewood Cliffs, NJ: Prentice-Hall.

Martensen, A., \& Gronholdt, L. (2001). Using employee satisfaction measurement to improve people management: An adaptation of Kano's quality types. Total Quality Management, 12 (7/8), 949-957.

McCarthy, A., \& Cleveland, J.N. (2005). An investigation of work-family conflict in the Irish hotel sector. Paper presented at the European Academy of Management Irish hotel sector. Paper presented at the Europ
(EURAM) Conference, Munich, Germany, 07 May.

McDonough, P. (2000). Job insecurity and health. International Journal of Health Services, 30(3), 453-476. http://dx.doi.org/10.2190/BPFG-X3ME-LHTA-6RPV

Meyer, J.P., Stanley, D.J., Herscovitch, L.H., \& Laryssa, T. (2002). Affective, continuance and normative commitment to the organization: A meta-analysis of antecedents, correlates and consequences. Journal of Vocational Behavior, 61, 20-52. http:// dx.doi.org/10.1006/jvbe.2001.1842

Mount, M., Ilies, R., \& Johnson, E. (2006). Relationship of personality traits and counterproductive work behaviors: The mediating effects of job satisfaction Personnel Psychology, 59, 591-622. http://dx.doi.org/10.1111/j.17446570.2006.00048.x

Mowday, R., Steers, R., \& Porter, L.W. (1979). The measurement of organizational commitment. Journal of Vocational Behaviour, 14, 224-247. http://dx.doi. org/10.1016/0001-8791(79)90072-1

Nunnally, J.C., \& Bernstein, I.H. (1994). Psychometric theory. (3rd edn.). New York, NY: McGraw-Hill.

Ostroff, C., \& Schulte, M. (2007). Multiple perspectives of fit in organizations across levels of analysis. In C. Ostroff \& T.A. Judge (Eds.), Perspectives on organizational fit, (pp. 3-69). New York, NY: Lawrence Erlbaum. 
Paulina, M., Fergusona, R., \& Bergeronb, J. (2006). Service climate and organizational commitment: The importance of customer linkages. Journal of World Business, 59(8), 906-915.

Pervin, L.A. (1968). Performance and satisfaction as a function of individua environment fit. Psychological Bulletin, 69(1), 56-68. http://dx.doi.org/10.1037/ h0025271

Pillay, R. (2009). Work satisfaction of professional nurses in South Africa: A comparative analysis of the public and private sectors. Human Resources for Health, 7(15), 1-10.

Poelmans, S., \& Sahibzada, K. (2004). A multi-level model for studying the contex and impact of work-family policies and culture in organizations. Huma Resource Management Review, 14, 409-431. http://dx.doi.org/10.1016/j. hrmr.2004.10.003

Probst, T.M. (2002). Layoffs and tradeoffs: Production, quality, and safety demands under the threat of job loss. Journal of Occupational Health Psychology, 7(3), 211-220. http://dx.doi.org/10.1037/1076-8998.7.3.211

Rahman, S., \& Bullock, P. (2005). Soft TQM, hard TQM, and organizational performance relationships: An empirical investigation. Omega, 33(1), 73-83. http://dx.doi. org/10.1016/j.omega.2004.03.008

Ramasodi, J.M.R. (2010). Factors influencing job satisfaction among healthcare professionals at South Rand Hospital. Master's thesis, Faculty of Health Systems Management and Policy, University of Limpopo, South Africa.

Reynolds, J. (2005). In the face of conflict: Work-life conflict and desired work hour adjustments. Journal of Marriage and Family, 67, 1313-1331. http://dx.doi. org/10.1111/j.1741-3737.2005.00219.x

Saari, L.M., \& Judge, T.A. (2004). Employee attitudes and job satisfaction. Human Resource Management, 43(1), 395-407. http://dx.doi.org/10.1002/hrm.20032

Scroggins, W.A. (2007). An examination of the additive versus convergent effects of employee perceptions of fit. Journal of Applied Social Psychology, 37, 1649-1665. http://dx.doi.org/10.1111/j.1559-1816.2007.00231.x

Sieger, P., Bernhard, F., \& Frey, U. (2011). Affective commitment and job satisfaction among non-family employees: Investigating the roles of justice perceptions and psychological ownership. Journal of Family Business Strategy, 2(1), 78-89.

Siew, P.L., Chitpakdee, B., \& Chontawan, R. (2011). Factors predicting organizational commitment among nurses in state hospitals, Malaysia. The International Medical Journal, 10(2), 21-28.

Smith, V. (2010). Enhancing employability: Human, cultural, and social capital in an era of turbulent unpredictability. Human Relations, 63(2), 279-303. http://dx.doi. org $/ 10.1177 / 0018726709353639$

Song, Z., \& Chon, K. (2012). General self-efficacy's effect on career choice goals via vocational interests and person job fit: A mediation model. International Journa of Hospitality Management, 31(1), 798-808. http://dx.doi.org/10.1016/j. ijhm.2011.09.016

Spector, P.E. (1985). Job satisfaction: Application, assessment, causes, and consequences. London, UK: Sage Publications.
Subramaniam, N., \& Mia, L. (2003). A note on work-related values, budget emphasis and managers' organisational commitment. Management Accounting Research, 14, 389-408. http://dx.doi.org/10.1016/j.mar.2003.07.001

Sverke, M., \& Goslinga, S. (2003). The consequences of job insecurity for employers and unions: Exit, voice, and loyalty. Economic and Industrial Democracy, 24(1), 241-270. http://dx.doi.org/10.1177/0143831X03024002005

Tak, J. (2007). Antecedents of person-job fit and its relation to intention to leave based on a sample of newcomers. Korean Journal of Industrial and Organizational Psychology, 20, 459-473.

Tsai, M.T., \& Huang, C.C. (2007). The relationship among ethical climate types, facets of job satisfaction and the three components of organizational commitment: A study of nurses in Taiwan. Journal of Business Ethics, 80, 565-581. http://dx.doi. org/10.1007/s10551-007-9455-8

Turnley, W.H., Bolino, M.C., Lester, S.W., \& Bloodgood, J.M. (2003). The impact of psychological contract fulfilment on the performance of in-role and organizational citizenship behaviours. Journal of Management, 29(2), 187-206. http://dx.doi org/10.1177/014920630302900204

Van Praag, B.M., \& Ferrer-i-Carbonell, A., 2008. Happiness quantified. Oxford, UK: Oxford University Press.

Verquer, M.L., Beehr, T.A., \& Wagner, S.H. (2003). A meta-analysis of the relations between person-organization $\mathrm{Wt}$ and work attitudes. Journal of Vocational Behavior, 63, 473-489. http://dx.doi.org/10.1016/S0001-8791(02)00036-2

Visser, J., McKenzie, A., \& Marais, D. (2012). Job satisfaction of South African registered dieticians. South African Journal of Clinical Nutrician, 25(3), 112-119.

Vogel, R.M., \& Feldman, D.C. (2009). Integrating the levels of person-environment fit: The roles of vocational fit and group fit. Journal of Vocational Behavior, 75, 68-81. http://dx.doi.org/10.1016/j.jvb.2009.03.007

Wegge, J., Schmidt, K., Parkes, C., \& Van Dick, K. (2007). Taking a sickie: Job satisfaction and job involvement as interactive predictors of absenteeism in a public organization. Journal of Occupational and Organizational Psychology, 80(1) 77-89. http://dx.doi.org/10.1348/096317906X99371

Yea, J., Cardon, M.S., \& Rivera, E. (2012). A mutuality perspective of psychological contracts regarding career development and job security. Journal of Business Research, 65, 294-301. http://dx.doi.org/10.1016/j.jbusres.2011.03.006

Yee, R.Y.Y., Yeung, A.C.L., \& Cheng, T.C.E. (2008). The impact of employee satisfaction on quality and profitability in high-contact service industries. Journal of Operation Management, 26(1), 651-668. http://dx.doi.org/10.1016/j.jom.2008.01.001

Yoon, M.H., \& Suh, J. (2003). Organizational citizenship behaviors and service quality as external effectiveness of contact employees. Journal of Business Research, 56(8), 597-611. http://dx.doi.org/10.1016/S0148-2963(01)00290-9

Zhao, X.R., \& Namasivayam, K. (2012). The relationship of chronic regulatory focus to work family conflict and job satisfaction. International Journal of Hospitality Management, 31(1), 458-467. http://dx.doi.org/10.1016/j.ijhm.2011.07.004

Zikmund, W.J., \& Babin, B.J. (2009). Essentials of marketing research. USA: Cengage Learning. 